\title{
A Mixed distribution with EVI and GEV components for analyzing heterogeneous samples
}

\author{
C. Escalante-Sandoval \\ División de Ingeniería Civil y Geomática \\ Facultad de Ingeniería, UNAM \\ E-mail:caes@servidor.unam.mx
}

(Recibido: agosto de 2006; aceptado: abril de 2007)

\begin{abstract}
Flood char ac ter is tics are re quired to solve sev eral wa ter-engineering prob lems. Tra ditionalflood fre quency anal y sis in volves the as sump tion of ho mogene ity of the flood distribution. However, floods are of tengenerated by distributions composed of a mix ture of two or more pop u la tions. Differences be tween the pop u la tions may be the result, for instance, of the ENSO phe nome non. If these phys ical processes are not con sid ered in conven tional flood fre quency anal $y$ sis, the T-year flood es ti mate can be in efficient for design pur poses. In or der to model het ero geneous sam ples, a mixed dis tribu tion with Extreme Value Type I (EV1 or Gumbel) and Gen eral Ex treme Value (GEV) com po nents is proposed. A region in North western Mex ico with 35 gaug ing sta tions has been selected to ap ply the model and at-site quantiles were es ti mated based on the max i mum like lihood procedure. Results produced by fit ting the EV1-GEV dis tribu tion were com pared through the use of a good ness-of-fit test with those ob tained by the mixed Gumbel and mixed GEV dis tribu tions. The EV1-GEV dis tribu tion was the best op tion for the $40 \%$ of analyzed samplesand thusit is suggested its ap plication when model ing heterogeneous se ries in flood fre quency anal y sis.
\end{abstract}

Keywords: Heterogeneous samples, flood frequencyanal ysis, mixed dis tributions, maximumlikelihoodparameterestimation.

\section{Resumen}

Muchos problemas en ingeniería hidráulica requieren conocer las características de una creciente. El análisis tradicional de frecuencias implica la consideración de homogeneidad de la serie. Sin embargo, en ocasiones los gastos máximos anuales son generados por distribuciones formadas por dos o más poblaciones. La diferencia entre poblaciones puede ser el resultado, entre otros, de la presencia del fenómeno ENSO. Si estos procesos físicos no se consideran en el análisis convencional, el evento estimado de cierto período de retorno puede ser ineficiente para propósitos de diseño. Con el fin de modelar muestras heterogéneas se propone la aplicación de una distribución mezclada, cuyas componentes son la distribución de Valores Extremos Tipo 1 (VE1 o Gumbel) y la General de Valores Extremos (GVE). Para aplicar el modelo se eligió una región del Noroeste de México que cuenta con 35 estaciones de aforos y se empleó la técnica de máxima verosimilitud para la estimación de los eventos de diseño. Los resultados de la distribución VE1-GVE, se compararon con aquellos obtenidos con las distribuciones Gumbel mixta y GVE mixta, a través de un 
criterio de bondad de ajuste. La distribución EV1-GVE fue la de mejor ajuste en el $40 \%$ de las muestras analizadas, por lo que se sugiere su aplicación en el caso de requerir estimar eventos de diseño a partir de series no homogéneas.

Descriptores: Muestras heterogéneas, análisis de frecuencias de crecientes, distribuciones mezcladas, estimación de parámetros por máxima verosimilitud.

\section{Introduction}

The objective of flood frequency analysis is to estimate the flood magnitude corresponding to any return period of occurrence through the use of probability distributions, which are needed in many studies and projects such as flood plain delineation, flood protection works, river crossings, and channel improvements.

Most flood studies have been analyzed through the use univariate distributions. Several efforts have been made to provide physical and statistical basics for selecting the type of probability distribution function that best fits the frequency distribution of the actual data. One common assumption in statistical analysis of flood frequency is the homogeneity of flood distributions. However, floods are often generated by distributions composed of a mixture of two or more populations. Differences between the populations may be the result of El Niño or La Niña oscillations. The occurrences of this phenomenon modify the normal precipitation patterns in Mexico (Cavazos and Hastenrath, 1990; Magaña et d., 2003; Magaña and Ambrizzi, 2005). Its signal reflects in more intense winter precipitation in the Northern states, particularly in Northwestern Mexico. As mentioned by Alila and Mtiraoui (2002) if these physical processes are not considered in conventional flood frequency analysis, the T-year flood estimate can be inefficient for design purposes.

The Mexican government has recognized that climate variability affects many of the its socio-economical activities and has begun to implement actions to diminish the negative effects of extreme climate conditions (floods and droughts). However, poverty has forced people to live almost on the water of rivers, situation that becomes an additional problem for the local governments. In order to protect their lives and goods is very important to account with an additional mathematical tool that might reduce the uncertainties in computing the design events for different return periods, which are needed in many studies and projects such as flood plain delineation.

In order to estimate more efficient quantiles of short or heterogeneous samples, a mixed distribution with Extreme Value Type I (EV1 or Gumbel) and General Extreme Value (GEV) components for the maxima is proposed and it will be called EV1-GEV distribution.

\section{Mixed distributions}

The use of a mixture of probability distributions functions for modeling samples of data coming from two populations have been proposed long time ago (Mood et al , 1974):

$$
\operatorname{Pr}(X \leq x)=F(x)=p F_{1}(x)+(1-p) F_{2}(x)
$$

Where $p$ is a factor used to weigh the relative contribution of each population $(0<p<1)$, and $F(x)$ is the composite exceedance probability. $F_{1}(x)$ and $F_{2}(x)$ are the components in the mixture. 


\section{Escalante-Sandoval}

\section{Mixed Gumbel Distribution}

If $F_{1}(x)$ and $F_{2}(x)$ of equation (1) are Gumbel distributions (NERC, 1975) then the five-parameter mixture model of annual floods is (Raynal and Guevara, 1997):

$$
F(x)=p \exp ^{-\exp ^{-\left(\frac{x-v_{1}}{\alpha_{1}}\right)}}+(1-p) \exp ^{-\exp -\left(\frac{x-v_{2}}{\alpha_{2}}\right)}
$$

where $v_{1}, \alpha_{1}$ and $v_{2}, \alpha_{2}$ are the location and scale parameters for the first and second population, respectively

The corresponding probability density function is

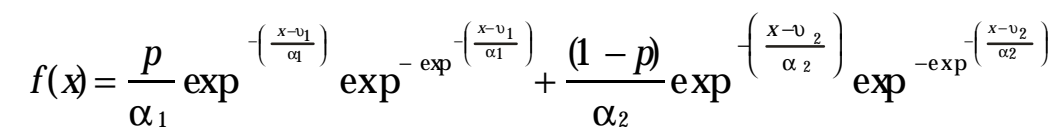

\section{Mixed General Extreme Value Distribution}

If $F_{1}(x)$ and $F_{2}(x)$ of equation (1) are GEV distributions (NERC, 1975) then the seven- parameter mixture model of annual floods is (Raynal and Santillan, 1986):

$$
F(x)=p \exp \left\{-\left[1-\left(\frac{x-\omega_{1}}{\lambda_{1}} \beta_{1}\right]^{1 / \beta_{1}}\right\}+(1-p) \exp \left\{-\left[1-\left(\frac{x-\omega_{2}}{\lambda_{2}} \beta_{2}\right]^{1 \beta_{2}}\right\}\right.\right.
$$

Where $\omega_{1}, \lambda_{1}, \beta_{1}$ and $\omega_{2}, \lambda_{2}, \beta_{2}$ are the location, scale and shape parameters for the first and second population, respectively.

The corre sponding prob a bility density func tion is

$$
\begin{gathered}
f(x)=\frac{p}{\lambda_{1}} \exp \left\{-\left[1-\left(\frac{x-\omega_{1}}{\lambda_{1}}\right) \beta_{1}\right]^{1 / \beta_{1}}\right\}\left[1-\left(\frac{x-\omega_{1}}{\lambda_{1}}\right) \beta_{1}\right]^{1 / \beta_{1}-1}+ \\
\frac{(1-p)}{\lambda_{2}} \exp \left\{-\left[1-\left(\frac{x-\omega_{2}}{\lambda_{2}}\right) \beta_{2}\right]^{1 / \beta_{2}}\right\}\left[1-\left(\frac{x-\omega_{2}}{\lambda_{2}}\right) \beta_{2}\right]^{1 / \beta_{2}-1}
\end{gathered}
$$

\section{EV1-GEV Distribution}

Assuming that first and second populations behave as EV1 and GEV distributions, respectively, equation (1) yields to the six-parameter mixture model of annual floods:

$$
F(x)=p \exp ^{-\exp -\left(\frac{x-v}{\alpha}\right)}+(1-p) \exp \left\{-\left[1-\left(\frac{x-\omega}{\lambda}\right)\right]^{1 / \beta}\right\}
$$

Where $v, \alpha$ and $\omega, \lambda$ are the location and scale parameters for the first and second population, respectively; $\beta$ is the shape parameter for the second population. 
The corresponding probability density function is

$$
f(x)=\frac{p}{\alpha} \exp ^{-\left(\frac{x-v}{\alpha}\right)} \exp ^{-\exp -\left(\frac{x-v}{\alpha}\right)}+\frac{(1-p)}{\lambda}\left[1-\left(\frac{x-\omega}{\lambda}\right) \beta\right]^{1 / \beta-1} \exp \left\{-\left[1-\left(\frac{x-\omega}{\lambda}\right) \beta\right]^{1 / \beta}\right\}
$$

\section{Estimation of parameters by maximum likelihood}

The likelihood function of $n$ random variables is defined to be the joint density of $n$ random variables and it is a function of the parameters. If $X_{1}, X_{2}, \ldots, X_{n}$ is a random sample of a univariate density function, the corresponding likelihood function is (Mood et al.,1974):

$$
L(x, \underline{\theta})=\prod_{i=1}^{n} f\left(x_{i}, \underline{\theta}\right)
$$

The logarithmic function will be used instead of the likelihood function because it is easier to handle. So, equation (8) is transformed:

$$
\operatorname{InL}(x, \underline{\theta})=\operatorname{In} \prod_{i=1}^{n} f\left(x_{i}, \underline{\theta}\right)
$$

Where $L$ is called the likelihood function, $\ln$ is the natural logarithm, $\underline{\theta}$ is the set of parameters to be estimated and $f(x, \underline{\theta})$ is the EV1-GEV density function, thus

$$
\operatorname{In} L(x, \underline{\theta})=\sum_{i=1}^{n} \operatorname{In}\left\{\begin{array}{c}
\frac{p}{\alpha} \exp ^{-\left(\frac{x-v}{\alpha}\right)} \exp ^{-\exp }-\frac{\left(\frac{x-0}{\alpha}\right)}{\lambda}\left[1-\left(\frac{x-\omega}{\lambda}\right) \beta\right]^{1 / \beta-1} \exp \left\{-\left[1-\left(\frac{x-\omega}{\lambda}\right) \beta\right]^{1 / \beta}\right\}
\end{array}\right.
$$

And the corresponding first order partial derivatives of such function with respect to each of the parameters are

$$
\begin{gathered}
\frac{\partial \operatorname{In} L}{\partial v}=\frac{p}{\alpha^{2}} \sum_{i=1}^{n} \frac{1}{f(x)}\left\{\exp ^{-\exp }-\left(\frac{x-v}{\alpha}\right)\left[\exp ^{-2\left(\frac{x-v}{\alpha}\right)}-\left(\frac{x-v}{\alpha}\right)\right]\right\} \\
\frac{\partial \operatorname{In} L}{\partial \alpha}=-\frac{p}{\alpha^{2}} \sum_{i=1}^{n} \frac{1}{f(x)}\left\{\exp ^{-\exp }-\left(\frac{x-v}{\alpha}\right)\left[\exp ^{-\left(\frac{x-v}{\alpha}\right)}+\exp ^{-2\left(\frac{x-v}{\alpha}\right)}-(x-v)\right]\right\} \\
\frac{\partial \operatorname{In} L}{\partial \omega}=-\frac{(1-p)}{\lambda^{2}} \sum_{i=1}^{n} \frac{1}{f(x)}\left\{\left\{(1-\beta)\left[1-\left(\frac{x-\omega}{\lambda} \beta\right]^{1 / \beta-2}-\left[1-\left(\frac{x-\omega}{\lambda}\right) \beta\right]^{2 \beta-2}\right\}\right\}\right.
\end{gathered}
$$




$$
\begin{aligned}
& \left.\frac{\partial \operatorname{In} L}{\partial \lambda}=\frac{(1-p)}{\lambda^{2}} \sum_{i=1}^{n} \frac{1}{f(x)}\left\{\begin{array}{r}
-\exp \left\{-\left[1-\left(\frac{x-\omega}{\lambda} \beta\right]^{1 / \beta}\right\}\left[1-\left(\frac{x-\omega}{\lambda}\right) \beta\right]^{1 / \beta-1}+\right. \\
(x-\omega) f(x)\left\{(1-\beta) /\left[1-\left(\frac{x-\omega}{\lambda} \beta\right]-\left[1-\left(\frac{x-\omega}{\lambda}\right) \beta\right]^{1 / \beta-1}\right\}\right.
\end{array}\right\}\right\} \\
& \frac{\partial \operatorname{In} L}{\partial \beta}=\frac{(1-p)}{\lambda^{2}} \sum_{i=1}^{n} \frac{1}{f(x)}\left\{\exp \left\{-1-\left(\frac{x-\omega}{\lambda}\right) \beta\right]^{1 / \beta}\left\{\begin{array}{c}
\frac{1}{\beta}\left(\frac{x-\omega}{\lambda}\right)\left[1-\left(\frac{x-\omega}{\lambda}\right)\right]^{1 / \beta-2} \\
\beta^{2} \operatorname{In}\left[1-\left(\frac{x-\omega}{\lambda}\right)\right]\left[1-\left(\frac{x-\omega}{\lambda}\right)\right]^{1 / \beta-1} \\
-\left(\frac{x-\omega}{\lambda}\right)\left(\frac{1}{\beta}-1\right) /\left[1-\left(\frac{x-\omega}{\lambda}\right)\right] \\
-1 \frac{1}{\beta^{2}} \operatorname{In}\left[1-\left(\frac{x-\omega}{\lambda}\right) \beta\right]
\end{array}\right\}\right\}
\end{aligned}
$$

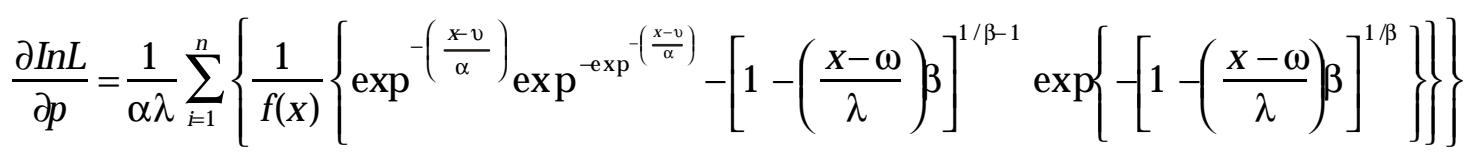

The exact solution provided by the system of equations (11)-(16) is not known, so the maximum likelihood estimators of the parameters were obtained by the direct maximization of the log-likelihood function (eq. 10), which is constrained to $\alpha>0, \lambda>0,0<p<1$, and $x>0$. The suggested procedure is the constrained multivariable Rosenbrock method (Kuester and Mize, 1973).

As it is known, in any of the multivariable constrained non-linear optimization techniques, global optimality is never assured. Therefore, care must be taken in order to avoid a local optimum. It is suggested to start always with values of the location, scale and shape parameters computed by considering the sample divided into two equal parts. If sample is sorted in decreasing order of magnitude, the first set of data is fitted to the univariate GEV distribution (Prescott and
Walden, 1980), and the second one to the univariate Gumbel distribution (NERC, 1975). The initial value of the association parameter $p$ will be equal to 0.5 .

For the mixed Gumbel and the mixed GEV distributions parameters are estimated following the same optimization procedure.

\section{Case study}

A region located in Northwestern Mexico, with a total of 35 gauging stations was selected to apply the EV1-GEV distribution to flood frequency analysis. Table 1 shows statistical characteristics of data for each station in the region.

In the area considered in this study, flood outliers correspond to observed rainfall values much higher than the other annual 
maxima. Such extremely heavy rainfall is due to special meteorological conditions in connection with ENSO events in the Pacific Ocean. In the analyzed area, $62 \%$ of the highest annual maximum discharges gauged were generated in an El Niño year and 38\% for its counterpart, La Niña.

Results provided by the EV1-GEV distribution were compared with those produced by the mixed Gumbel and mixed GEV distributions. For each station the best one was chosen according to the criterion of minimum standard error of fit $(S E)$, as defined by Kite (1988):

$$
S E=\left[\sum_{i=1}^{n}\left(g_{i}-h_{i}\right)^{2} /(n-q)\right]^{1 / 2}
$$

Where $g_{i}, i=1, \ldots n$ are the $h_{i}, i=1, \ldots n$ recorded events; are the event magnitudes computed from the probability distribution at probabilities obtained from the sorted ranks of, $g_{i}, i=1, \ldots, n, n$ is the length of record, and $q$ is the number of parameters estimated for the mixed distribution. For the mixed distributions, Gumbel, GEV and EV1-GEV $q$ will be equal to 5, 7 and 6, respectively.

In table 2 is depicted the $S E$ for all mixed distributions along with the best model for the sample of data considered.

The final at-site design events $Q\left(\mathrm{~m}^{3} / \mathrm{s}\right)$ for different return periods $\mathrm{T}$ (years) in each station are presented in Table 3.

In some sites a comparison is made among different at-site design events (Table 4). For instance, in station Chinipas the computed SE are very similar, however, as return period increases, differences among flood estimates are more significant. A bad selection of the best distribution in the analyzed site can substantially modify the design event and that the hydraulic project might become economically unfeasible or unsafe.

An additional problem is when a short record is used (less than 30 years), because there is an increased risk that the flood estimate will not provide adequate protection of designated uses. One way to reduce the bias or uncertainty in the flood estimate is to use a regional data set with observations from several sites.

Mixed Gumbel, GEV and EV1-GEV distributions can be easily used to obtain regional at-site estimates of floods by using the station-year method in regions with heterogeneous sample data. The general procedure of this regional technique can be found in paper written by Cunnane (1988).

This regional technique was not applied in the paper and it just was mentioned to be considered for users in their hydrological analyses. 


\section{Escalante-Sandoval}

Table 1. Statis tical char ac ter is tics of flood data for each analyzed gauging station

\begin{tabular}{|c|c|c|c|c|c|c|c|c|}
\hline$\underline{\mathbf{m}}$ & Gauging Station & $\begin{array}{l}\text { Years of } \\
\text { record }\end{array}$ & $\begin{array}{l}\text { Period of } \\
\text { record } \\
\end{array}$ & Me an & $\begin{array}{l}\text { Standa id } \\
\text { Deviation }\end{array}$ & Co efficient of & Coefficien to & Coefficient of \\
\hline 1 & Aca titan & 31 & $1955-1985$ & 1031.6 & 864.5 & 2.63 & 12.79 & 0.84 \\
\hline 2 & Alam os & 22 & $1948-1969$ & 247.6 & 178.8 & 0.83 & 3.60 & 0.72 \\
\hline 3 & Badira guato & 27 & $1959-1985$ & 957.9 & 1853.6 & 3.92 & 20.65 & 1.94 \\
\hline 4 & Bami cori & 32 & $1951-1982$ & 194.5 & 176.7 & 1.39 & 4.46 & 0.91 \\
\hline 5 & Cazande & 19 & $1967-1985$ & 555.0 & 727.9 & 3.06 & 15.04 & 1.31 \\
\hline 6 & Chini pas & 21 & $1965-1985$ & 1061.0 & 524.4 & 0.31 & 2.83 & 0.49 \\
\hline 7 & Choix & 29 & $1955-1983$ & 392.9 & 336.5 & 2.59 & 11.84 & 0.86 \\
\hline 8 & El Ble dal & 48 & $1938-1985$ & 286.0 & 273.4 & 2.83 & 13.92 & 0.96 \\
\hline 9 & El Mahone & 20 & $1966-1985$ & 198.4 & 26.3 & 0.69 & 5.96 & 0.13 \\
\hline 10 & El Naranjo & 47 & $1939-1985$ & 621.9 & 655.5 & 1.87 & 6.98 & 1.05 \\
\hline 11 & El Queli te & 26 & $1960-1985$ & 468.5 & 445.2 & 1.72 & 6.27 & 0.95 \\
\hline 12 & Guamuchil & 36 & $1938-1973$ & 605.9 & 630.4 & 3.09 & 16.22 & 1.04 \\
\hline 13 & Guatenipa & 21 & $1965-1985$ & 1888.8 & 1393.2 & 0.84 & 3.2 & 0.74 \\
\hline 14 & Huites & 53 & 1941-1993 & 2942.0 & 3124.3 & 2.63 & 10.39 & 1.06 \\
\hline 15 & Ixpali mo & 31 & $1953-1983$ & 1317.8 & 1218.2 & 2.79 & 12.68 & 0.92 \\
\hline 16 & Jaina & 46 & 1941-1986 & 1197.4 & 1189.9 & 3.20 & 16.30 & 0.99 \\
\hline 17 & La Huerta & 17 & $1969-1985$ & 934.2 & 574.3 & 0.29 & 2.43 & 0.61 \\
\hline 18 & La Tina & 24 & $1960-1983$ & 106.5 & 152.3 & 4.00 & 22.39 & 1.43 \\
\hline 19 & Las Cañas & 24 & 1948-1971 & 2497.0 & 3194.2 & 1.60 & 4.84 & 1.28 \\
\hline 20 & Palo Dulce & 29 & $1957-1985$ & 975.9 & 1195.7 & 4.40 & 25.89 & 1.23 \\
\hline 21 & Palo s Bl ancos & 47 & $1939-1985$ & 1481.8 & 1726.4 & 1.92 & 7.85 & 1.17 \\
\hline 22 & Peric os & 26 & $1960-1985$ & 201.0 & 95.1 & 0.14 & 2.56 & 0.47 \\
\hline 23 & Piaxtla & 16 & $1958-1973$ & 1419.8 & 1587.8 & 2.48 & 10.79 & 1.12 \\
\hline 24 & PteSud Pa cífic o & 35 & $1924-1588$ & 2961.0 & 2204.9 & 1.41 & 7.20 & 0.74 \\
\hline 25 & Puen te $C$ añed o & 22 & $1932-153$ & 1116.0 & 932.7 & 0.76 & 3.35 & 0.84 \\
\hline 26 & San Fran cisco & 33 & $1941-1973$ & 1724.6 & 1450.1 & 1.89 & $7.0 B$ & 0.84 \\
\hline 27 & San Ignac io & 19 & $1967-1985$ & 1622.4 & 813.4 & 1.70 & 7.38 & 0.50 \\
\hline 28 & Sanalona & 42 & 1944-1985 & 447.3 & 505.4 & 2.99 & 13.49 & 1.13 \\
\hline 29 & San ta Cruz & 43 & $1943-1985$ & 1269.7 & 1216.5 & 2.94 & 14.86 & 0.96 \\
\hline 30 & Tamazula & 23 & $1962-1984$ & 583.6 & 278.0 & 1.38 & 5.46 & 0.48 \\
\hline 31 & Tecusiapa & 17 & $1958-1974$ & 975.7 & 792.7 & 1.66 & 6.49 & 0.81 \\
\hline 32 & Toaha yan a & 29 & 1957-1985 & 1048.9 & 629.7 & 0.67 & 3.19 & 0.60 \\
\hline 33 & Urique & 19 & $1967-1985$ & 302.6 & 148.0 & 1.16 & 6.81 & 0.49 \\
\hline 34 & Zapotitlán & 22 & $1960-1981$ & 624.6 & 645.4 & 2.03 & 9.09 & 1.03 \\
\hline 35 & Zopilote & 47 & $1939-1985$ & 363.2 & 275.9 & 0.69 & 2.81 & 0.76 \\
\hline
\end{tabular}


DOI: http://dx.doi.org/10.22201/fi.25940732e.2007.08n3.011

A Mixed distribution with EVI and GEV compo nents foranalyzing hetero ge neous samples

Table 2. The computed SE (in $\left.\mathrm{m}^{3} / \mathrm{s}\right)$ for each analyzed gauging station

\begin{tabular}{|c|c|c|c|c|}
\hline Gauging $S$ tation & EVI-GVE & Mixed G umbel & Mixed GVE & Best d istribution \\
\hline A cati tan & 308.9 & 337.0 & 386.3 & EV1-GVE \\
\hline Alamos & 25.9 & 28.4 & 25.8 & Mixed GV E \\
\hline Badirag uato & 769.5 & 921.3 & * & EV1-GVE \\
\hline Bamicori & 30.1 & 46.5 & 30.8 & EV1-GVE \\
\hline Cazan ate & 377.9 & 443.8 & 372.1 & Mixed GV E \\
\hline Chinipas & 89.2 & 81.6 & 91.2 & Mixed Gumbel \\
\hline Choix & 152.7 & 118.5 & 146.2 & Mixed Gumbel \\
\hline El Bledal & 74.7 & 69.4 & 86.3 & Mixed Gumbel \\
\hline El Mahone & 24.0 & 8.5 & 8.6 & Mixed Gumbel \\
\hline El Nararjo & 112.0 & 174.4 & 125.9 & EV1-GVE \\
\hline El Quelite & 126.1 & 143.1 & 116.3 & Mixed GV E \\
\hline Guamuchil & 241.9 & 263.2 & 352.1 & EV1-GVE \\
\hline Guatenipa & 225.1 & 355.9 & 337.0 & EV1-GVE \\
\hline Huites & 614.1 & 987.0 & 805.6 & EV1-GVE \\
\hline Ixpal ino & 390.3 & 370.8 & * & Mixed Gumbel \\
\hline Jaina & 402.8 & 411.2 & * & EV1-GVE \\
\hline La Huer ta & 364.0 & 99.0 & * & Mixed Gumbel \\
\hline La Tina & 122.4 & 105.4 & 127.3 & Mixed Gumbel \\
\hline Las Cañas & * & 2139.1 & 790.5 & Mixed GV E \\
\hline PaloDuke & 884.9 & 963.3 & 900.5 & EV1-GVE \\
\hline Palos Blancos & 340.1 & 550.9 & 294.4 & Mixed GVE \\
\hline Pericos & 19.2 & 18.1 & 26.3 & Mixed Gumbel \\
\hline Praxtla & 641.0 & 502.5 & 828.6 & Mixed Gumbel \\
\hline Pte SudPacífico & 614.8 & 658.0 & 624.5 & EV1-GVE \\
\hline Puerte Cañedo & 149.8 & 135.6 & 174.8 & Mixed Gumbel \\
\hline San Fra a isco & 323.4 & 333.8 & 302.8 & Mixed GV E \\
\hline San Ignacio & 296.6 & 344.4 & 273.8 & Mixed GVE \\
\hline Sanalo na & 115.8 & 214.6 & 214.5 & EV1-GVE \\
\hline Santa Cruz & 390.9 & 341.4 & * & Mixed Gumbel \\
\hline Tamazula & 93.5 & 77.2 & * & Mixed Gumbel \\
\hline Tecusiapa & 278.5 & 211.9 & 308.8 & Mixed Gumbel \\
\hline Toaha y ana & 104.6 & 106.6 & 101.8 & Mixed GV E \\
\hline Unique & 92.2 & 44.1 & * & Mixed Gumbel \\
\hline Zapotitlán & 219.0 & 301.1 & 238.6 & EV1-GVE \\
\hline Zopi lote & 37.4 & 37.6 & 38.6 & EV1-GVE \\
\hline
\end{tabular}

* No conver gence was attained in the esti ma tion of param e ters 
DOI: http://dx.doi.org/10.22201/fi.25940732e.2007.08n3.011

\section{Escalante-Sandoval}

Table 3. Design events $Q\left(\mathrm{~m}^{3} / \mathrm{s}\right)$ for the best fitted distri bu tion in each analyzed gauging station

\begin{tabular}{|c|c|c|c|c|c|c|c|c|}
\hline \multirow[b]{2}{*}{ Gauging $\mathrm{S}$ tation } & \multicolumn{8}{|c|}{ Retu m period $\operatorname{Tr}(\mathrm{y}$ ears) } \\
\hline & 2 & 5 & D & 20 & 50 & 100 & 500 & 1000 \\
\hline Acatitan & 693.2 & 1610.3 & 2175.5 & 2720.9 & 3502.6 & 4168.2 & 6049.8 & 7039.0 \\
\hline Ala mos & 198.1 & 48.5 & 522.0 & 589.4 & 651.0 & 685.1 & 742.8 & 770.0 \\
\hline Ala mos & 203.9 & 396.2 & 496.0 & 585.3 & 697.6 & 7807 & 971.7 & 1053.6 \\
\hline Badirag ta to & 415.0 & 686.5 & 2369.1 & 4770.6 & 7736.6 & 10461.1 & 19586.4 & 5268.6 \\
\hline Bamicori & 116.4 & ऊ3.7 & 499.8 & 574.5 & 635.0 & 6652 & 706.8 & 717.3 \\
\hline Ca zanate & 304.9 & 728.5 & 1295.8 & 1944.6 & 2934.4 & 38240 & 6550.4 & 8097.6 \\
\hline Chinipas & 1050.5 & 1484.1 & 1751.1 & 2003.3 & 2327.4 & 2569.5 & 3128.1 & 3368.2 \\
\hline Choix & 299.7 & 500.4 & 713.5 & 1013.9 & 1419.1 & 1709.0 & 2359.6 & 2636.2 \\
\hline El Ble dal & 209.0 & 35.9 & 572.8 & 830.2 & 1147.9 & 1373.2 & 1879.4 & 2094.8 \\
\hline El Mahone & 197.7 & 214.6 & 226.9 & 240.4 & 260.5 & 2768 & 315.8 & 332.8 \\
\hline El Nara jo & 377.2 & 987.0 & 1647.7 & 2001.4 & 2450.2 & 2808.3 & 3753.9 & 4223.0 \\
\hline El Quelite & 307.1 & 749.0 & 1052.7 & 1384.2 & 1896.1 & 2357.1 & 3757.6 & 4543.1 \\
\hline Guamuchil & 431.4 & 80.3 & 1236.2 & 1728.5 & 2472.7 & 31140 & 4953.5 & 5935.7 \\
\hline Guatenipa & 1593.2 & 321.7 & 3903.2 & 4451.4 & 5041.7 & 54141 & 6096.2 & 6327.7 \\
\hline Huites & 1865.7 & 348.2 & 6929.2 & 9949.8 & 13232.7 & 15504.8 & 20439.9 & 22464.1 \\
\hline Ixpal ino & 963.7 & 1580.2 & 2334.1 & 3720.8 & 5550.2 & 6835.9 & 9716.7 & 10941.7 \\
\hline Jaima & 807.3 & 156.7 & 2480.2 & 3401.5 & 4707.4 & 5809.4 & 8894.1 & 10502.4 \\
\hline La Huer ta & 801.9 & 144.2 & 1627.1 & 1764.4 & 1937.2 & 2065.3 & 2359.5 & 2485.7 \\
\hline La Tina & 71.0 & 27.2 & 173.6 & 254.1 & 563.3 & 7269 & 1051.5 & 1184.8 \\
\hline Las Cañas & 929.2 & 432.3 & 7643.8 & 8899.5 & 9703.0 & 10022.1 & 10355.7 & 10416.1 \\
\hline PaloDuke & 676.4 & $1 \oplus 7.1$ & 1518.3 & 2137.7 & 3160.1 & 40129 & 6300.9 & 7450.2 \\
\hline Palos Blancos & 871.2 & $2 \notin 2.6$ & 3850.1 & 5076.2 & 6882.0 & 84325 & 12820.8 & 15123.2 \\
\hline Pericos & 199.4 & 74.6 & 319.7 & 362.0 & 416.2 & 4567 & 550.0 & 590.1 \\
\hline Praxtla & 781.0 & 1490.9 & 3902.2 & 5156.8 & 6582.3 & 76024 & 9910.7 & 10895.7 \\
\hline Pte SudPacifico & 2833.8 & 453.0 & 5709.2 & 6866.1 & 8493.5 & 98247 & 13327.1 & 15039.5 \\
\hline Puerte Cañedo & 894.5 & 1914.3 & 2424.0 & 2889.1 & 3478.1 & 3915.5 & 4921.8 & 5353.7 \\
\hline San Fra re isco & 1149.8 & 2590.9 & 3717.4 & 4733.3 & 6042.8 & 7045.4 & 9475.7 & 10577.5 \\
\hline San Ignacio & 1509.3 & 2246.5 & 2754.5 & 3308.9 & 4156.9 & 4911.2 & 7156.5 & 8391.5 \\
\hline Sanalo na & 301.4 & 517.5 & 764.3 & 1651.6 & 2296.9 & 25124 & 2728.8 & 2768.1 \\
\hline Santa Cruz & 927.0 & 1667.6 & 2625.1 & 3833.9 & 5249.3 & 6245.8 & 8480.8 & 9431.4 \\
\hline Tamazula & 510.4 & 747.8 & 939.4 & 1136.9 & 1398.4 & 1595.2 & 2049.7 & 2245.0 \\
\hline Tecusiapa & 698.5 & 1400.1 & 2112.2 & 2732.2 & 3480.1 & 4023.9 & 5262.5 & 5792.2 \\
\hline Toa ha y ana & 926.5 & 1666.1 & 1977.3 & 2214.4 & 2462.4 & 2615.7 & 2895.6 & 2995.6 \\
\hline Unique & 294.5 & 34.2 & 480.4 & 602.6 & 757.5 & 8726 & 1137.5 & 1251.2 \\
\hline Zapotitlán & 533.7 & $1 \oplus 9.7$ & 1517.6 & 1969.9 & 2646.9 & 3233.8 & 4911.4 & 5798.8 \\
\hline Zopi lote & 316.2 & 610.6 & 748.6 & 858.5 & 977.0 & 10520 & 1189.8 & 1236.8 \\
\hline
\end{tabular}


DOI: http://dx.doi.org/10.22201/fi.25940732e.2007.08n3.011

A Mixed distribution with EVI and GEV compo nents foranalyzing hetero ge neous samples

Table 4. Compar ison of design events $Q\left(\mathrm{~m}^{3} / \mathrm{s}\right)$ and $S E\left(\mathrm{in} \mathrm{m}^{3} / \mathrm{s}\right)$ for some selected stations of case study

\begin{tabular}{|c|c|c|c|c|c|c|c|c|c|c|}
\hline \multirow[b]{2}{*}{ G aug ing Sta tio $n$} & \multirow[b]{2}{*}{ D istribution } & \multicolumn{8}{|c|}{ Ret urn period $\operatorname{Tr}$ (years) } & \multirow[b]{2}{*}{$S E$} \\
\hline & & 2 & 5 & 10 & 20 & 50 & 100 & 500 & 1000 & \\
\hline \multirow[t]{3}{*}{ Chinipas } & EV1-G VE & 1040 & 1542 & 1752 & 1912 & 2079 & 2181 & 2359 & 2417 & 89.2 \\
\hline & Mixed GVE & 1040 & 1551 & 1763 & 1925 & 296 & 2203 & 2427 & 2573 & 91.2 \\
\hline & Mixed Gumbel* & 1051 & 1484 & 1751 & 2003 & 2327 & 2569 & 3128 & 3368 & 81.6 \\
\hline \multirow[t]{3}{*}{ Palo Duke } & EV1-GVE* & 676 & 1097 & 1518 & 2138 & 3160 & 4013 & 6301 & 7450 & 8849 \\
\hline & Mixed GVE & 672 & 1114 & 1539 & 2137 & 3262 & 4321 & 7402 & 9039 & 9005 \\
\hline & Mixed Gumbel & 702 & 1094 & 1395 & 1776 & 2866 & 4097 & 6984 & 8191 & 9633 \\
\hline \multirow[t]{3}{*}{ San Fr ancisco } & EV1-G VE & 1155 & 2524 & 3543 & 4626 & 656 & 7687 & 11879 & 14151 & 3234 \\
\hline & Mixed GVE* & 1150 & 2591 & 3717 & 4733 & 6043 & 7045 & 9476 & 10578 & 3028 \\
\hline & Mixed Gumbel & 1141 & 2613 & 3676 & 4605 & 5760 & 6613 & 8566 & 9404 & 3338 \\
\hline
\end{tabular}

* Best distri bu tion according to the minimum value of $S E$.

\section{Conclusions}

Floods are often generated by heterogeneous distributions composed of a mixture of two populations. Differences between the populations may be the result of a number of factors such as the El Niño/La Niña oscillations. In the analyzed area $62 \%$ of the highest annual maximum discharges (outliers) were generated in an El Niño year. The magnitude of these events is very important and floods can seriously affect people. For this reason, it is necessary to account with an additional mathematical tool that be able to reduce the uncertainty in estimating of de- sign events, which are needed in many water-engineering studies and projects.

In this paper a mixed distribution has been derived by considering different components in an opposite way as usually do. $F_{1}(x)$ and $F_{2}(x)$ of equation (1) were the EV1 and the GEV distributions, respectively.

Results shown that there exists a reduction in the standard error of fit when using the EV1-GEV distribution in comparison with the mixed Gumbel or mixed GEV distributions, and just in one out of the 35 analyzed cases, the proposed distribution could not reach convergence in the estimation of parameters process. By contrast, the Mixed GEV distribution had seven failures with the same estimation process.

In 13 sample data the EV1-GEV distribution produced the least standard error of fit $(40 \%$ of analyzed cases) and in other different cases it was very close to the mixed Gumbel and mixed GEV distributions, However, as it was shown, differences between at-site design events can be significant as return period increases. A bad selection of the best distribution in the analyzed site can substantially modify the design event and also that the hydraulic project might become economically unfeasible or unsafe. Thus, by taking into consideration the mixed flood distributions a more accurate, physically based flood frequency analysis can be obtained and sensible savings in costs of construction of flood protection structures can be expected. This can also improve the setting of flood plain limits and the safety of control structures. 


\section{Escalante-Sandoval}

\section{References}

Alila Y. and Mtiraoui A. (2002). Implications of Heterogeneous Flood-Frequency Distributions on Traditional Stream-Discharge Prediction Techniques. Hydrological Processes , 16:1065-1084.

Cavazos T. and Hastenrath S. (1990). Convection and Rainfall Over Mexico and their Modulation by the Southern Oscillation. International Journal of Climatology , 10: 377-386.

Kite G.W. (1988). Frequency and Risk Analyses in Hydrology. Water Resources Publications, Littleton, Colo rado, USA.

Kuester J.L. and Mize J.H. (1973). Optimization Techniques with FORTRAN. McGraw-Hill.

Magaña V. and Ambrizzi T. (2005). Dynamics of Subtropical Vertical Motions Over the Americas During El Niño Boreal Winters. Atmósfera, 18(4): 211-233.

Magaña V., Vázquez J., Pérez J. and Pérez J.B. (2003). Impact of El Niño on
Precipitation in Mexico. Geofísica Internacional , 42(3): 313-330.

Mood A., Graybill F. and Boes D. (1974). Introduction to the Theory of Statistics. Third Ed., McGraw-Hill.

NERC (1975). Natural Envi ron ment Research Council. Flood Studies Report I, Hydrologic Studies. Whitefriars Press Ltd., London, United Kingdom.

Prescott P. and Walden A. (1980). Maximum Likelihood Estimation of the Parameters of the Generalized Extreme Value Distribution. Biometrika, 67(3): 723-724.

Raynal J. and Guevara J. (1997). Maximum Likelihood Estimators for the two Populations Gumbel distribution. Hydrological Science and Technology Journal, 13(1-4):47-56.

Raynal J. and Santillan O. (1986). Maximum Likelihood Estimators of the Param e ters of the Mixed GEV Distri bution. IX Congreso Nacional de Hidráulica. AMH. Querétaro, Qro., Mex. pp. 79-90. (In Spanish)

\section{Semblanza del autor}

Dr. Carlos Agustín Escalante-Sandoval . Es doctor en ingeniería hidráulica por la Facultad de Ingeniería de la UNAM. Actualmente es profesor titular "C" de tiempo completo definitivo. Ha impartido 85 cursos en el Posgrado de la UNAM; dirigido 38 tesis de maestría y cinco de doctorado. Dentro de su producción académica se encuentran: 30 publicaciones en revistas con arbitraje, 45 en congresos nacionales e internacionales, 3 capítulos en libro, 2 libros como autor y otro como co-editor. Recibió la medalla Gabino Barreda por sus estudios de doctorado, el premio Distinción Universidad Nacional para Jóvenes Académicos en Docencia en Ciencias Exactas 1999 que otorga la UNAM y el Premio Nacional Enzo Levi "Investigación y Docencia en Hidráulica 2002", por parte de la Asociación Mexicana de Hidráulica. Es miembro del Sistema Nacional de Investigadores, Academia Mexicana de Ciencias, Academia de Ingeniería, Colegio de Ingenieros Civiles de México y la Asociación Mexicana de Hidráulica. 